\title{
Dokter Pustaka: Layanan Informasi Online Bidang Kesehatan Alumni Fakultas Kedokteran, Kesehatan Masyarakat dan Keperawatan Universitas Gadjah Mada Yogyakarta
}

\author{
Maniso Mustar ${ }^{1}$; Wahid Nashihuddin ${ }^{2}$ \\ ${ }^{1}$ Fakultas Kedokteran Kesehatan Masyarakat dan Keperawatan, Universitas Gadjah Mada \\ ${ }^{2}$ Magister Kajian Budaya dan Media, Manajemen Informasi dan Perpustakaan, Universitas Gadjah Mada
}

*Korespondensi: ariemaniso1205@ugm.ac.id

\begin{abstract}
Dokter Pustaka is a brand and media of digital literacy for alumni of FKKMK (Fakultas Kedokteran, Kesehatan Masyarakat dan Keperawatan) UGM who have worked as doctors, nurses, and residents. Through the "Dokter Pustaka" service, alumni can discuss, consult, and ask for references via-online in the health science from librarians without being limited by time and space. This paper aims to describe the service user profile; alumni understanding of health literacy; and utilization of library services in the library of FKKMK UGM. The study data is descriptive with a qualitative approach. Sources of study data are literature studies, WhatsApp-Group discussions, and questionnaires. Study respondents consist of 84 alumni of FKKMK UGM who had worked as doctors, nurses, and residents in Indonesia. The study results showed that the respondent's majority worked as specialist doctors (76 people) in hospitals throughout Indonesia. They argue that health literacy is one's knowledge and competence in the health field that is useful for making medical and clinical decision materials by procedures, medical service standards and evidence-based medicine (EBM) through the provision of up to date literature in the library or online database. Through "Dokter Pustaka" services, alumni obtain the scientific literature and the latest information in the health field easily, quickly, and free of charge without having to come to the library.
\end{abstract}

Keywords: information service; health literacy; digital literacy; whatsapp group; alumni; dokter pustaka

\begin{abstract}
Abstrak
Dokter Pustaka merupakan brand dan media literasi digital untuk para alumni FKKMK (Fakultas Kedokteran, Kesehatan Masyarakat dan Keperawatan) UGM yang telah bekerja sebagai dokter, perawat, dan residen. Melalui layanan Dokter Pustaka, alumni dapat berdiskusi, berkonsultasi, dan meminta referensi bidang kesehatan secara online kepada pustakawan tanpa dibatasi ruang dan waktu. Makalah ini bertujuan untuk mendeskripsikan profil pengguna layanan; pemahaman alumni terhadap literasi kesehatan; dan pemanfaatan layanan Dokter Pustaka Perpustakaan FKKMK UGM. Data kajian ini bersifat deskriptif dengan pendekatan studi kasus Sumber data kajian yaitu studi literatur, diskusi WhatsApp-Group, dan kuesioner. Responden kajian sejumlah 84 orang alumni FKKMK UGM yang telah bekerja sebagai dokter, perawat, dan residen di berbagai wilayah di Indonesia. Hasil kajian menunjukkan bahwa sebagai besar responden bekerja sebagai dokter spesialis (76 orang) di rumah sakit di seluruh Indonesia. Mereka berpendapat bahwa literasi kesehatan merupakan pengetahuan dan kompetensi seseorang terhadap bidang kesehatan yang berguna untuk pengambilan bahan keputusan medis dan klinis sesuai dengan prosedur, standar pelayanan medis dan evidance based medicine (EBM) melalui penyediaan literatur/referensi mutakhir di perpustakan atau database online. Melalui layanan Dokter Pustaka, alumni memperoleh literatur ilmiah dan informasi mutakhir bidang kesehatan dengan mudah, cepat, gratis tanpa harus datang ke perpustakaan.
\end{abstract}

Kata Kunci: layanan informasi; literasi kesehatan; literasi digital; whatsapp group; alumni; dokter pustaka

\section{PENDAHULUAN}

Perpustakaan sebagai lembaga layanan publik dituntut untuk memberikan pelayanan prima bagi masyarakat tanpa membedakan satu sama lain. Pelayanan prima di perpustakaan tidak harus bermodalkan materi yang besar, tetapi dilihat dari bagaimana cara lembaga komitmen dalam memanfaatkan keterbatasan fasilitas dan sumber daya informasi yang ada untuk suatu hasil yang optimal. Pustakawan sebagai motor penggerak layanan perpustakaan dituntut aktif, kreatif, dan inovatif untuk mewujudkan program pelayanan prima bagi pangguna (pemustaka) tanpa diskriminasi dengan keterbatasan sumber daya organisasi. Salah satu contoh program pelayanan 
prima di perpustakaan ini adalah layanan online yang merupakan layanan literasi digital bidang kesehatan melalui media sosial. Layanan online merupakan sarana penelusuran online disediakan untuk mempermudah pengguna dalam mencari informasi dan bertanya langsung kepada pustakawan yang bertugas di layanan online (Nashihuddin \& Tupan, 2013).

Dokter Pustaka merupakan layanan literasi digital yang dapat memberikan informasi sesuai dengan perkembangan ilmu kedokteran. Layanan ini diberikan melalui komunikasi dan interaksi antara alumni di daerah-daerah dengan pustakawan untuk mencapai perkembangan kesehatan tertinggi kepada masyarakat. Studi pemberian layanan kepada alumni merupakan bagian kegiatan orgaisasi yang tepat, selain untuk menyediakan berbagai literatur untuk mendukung kegiatan ekonomi mereka (yang sudah bekerja) juga untuk pemberian amal. Kebutuhan alumni terhadap almamater tempat kuliah sangat erat kaitannya dengan kepuasan selama mereka kuliah. Alumni dapat menyampaikan pengalaman dan meminta almamaternya untuk membantu memenuhi kebutuhan informasi mereka (Clotfelter, 2003).

Literasi digital merupakan keterampilan yang dibutuhkan setiap orang untuk mendapatkan informasi yang terus berkembang, melakukan berkomunikasi dan berinteraksi dengan yang lain, untuk memperoleh pekerjaan, mencapai kesuksesan ekonomi, dan berpartisipasi aktif dalam kewarganegaraan serta kolaboratif dengan jaringan online (Kim, Lee, \& Yi, 2017). Literasi digital memiliki banyak manfaat seperti cara untuk menemukan informasi yang bernilai dalam pengambilan keputusan yang lebih baik (Maulana, 2015). Literasi digital memiliki berbagai kelebihan untuk diterapkan dalam program Dokter Pustaka yang nantinya mampu memberikan informasi secara uptodate, membantu pekerjaan para dokter di daerah, berkolaborasi dalam jaringan online dengan para dokter alumni serta dapat menggali peran pustakawan dan perpustakaan dalam berpatisipasi terhadap masyarakat.

Salah satu cara adalah mencari tambahan pengetahuan melalui membaca berbagai media bahan bacaan yang sebagian besar tersedia di perpustakaan termasuk literasi digital (Saepudin, 2013). Keberhasilan program literasi digital di perpustakaan sangat tergantung pada teknologi informasi dan komunikasi yang digunakan untuk mentransmisikan data, informasi, dan/atau pengetahuan ke orang lain atau masyarakat. Pemanfaatan teknologi digital untuk peningkatan fungsi dan manfaat dari kegiatan literasi kesehatan, petugas harus memiliki keterampilan dalam membaca (huruf dan angka) seperti menavigasi sistem layanan kesehatan, komunikasi dengan penyedia layanan kesehatan, dan pengambilan keputusan bersama (Dunn \& Hazzard, 2019).

Dalam bidang kesehatan, program literasi digital seperti program biblioterapi dan literasi kesehatan masyarakat (melalui penyediaan bahan bacaan tepat guna dan berkulitas) akan sangat membantu program pemerintah untuk mewujudkan 'gerakan masyarakat sehat'. Metode biblioterapi dipilih karena dapat mendekatkan individu pada buku dan menjadikan individu terbiasa membaca (Dewi \& Prihartanti, 2014). Literasi kesehatan ini dianggap sebagai kemampuan literasi paling dasar seseorang untuk aktif berpartisipasi dalam kehidupan sosialekonomi masyarakat. Kemampuan seseorang dalam literasi kesehatan dapat dilihat dari pengetahuan seseorang terhadap variabel sosio-demografi, persepsi diri, kesehatan, dan kondisi kronis pada pasien pelayanan kesehatan primer (Wahyuningsih, 2019).

Program literasi digital bidang kesehatan di perpustakaan saat ini telah diimplementasikan oleh pustakawan di Perpustakaan Fakultas Kedokteran, Kesehatan Masyarakat dan Keperawatan Universitas Gadjah Mada Yogyakarta (FKKMK UGM) melalui layanan referensi online 'Dokter Pustaka'. Layanan ini berbeda dengan layanan Dokter Pustaka yang ada di tempat lain, seperti: (1) Taman Baca Dokter Pustaka di Rumah Singgah Peduli, merupakan pegiat literasi menyediakan taman bacaan bagi masyarakat melalui donasi buku bacaan umum dan buku bergambar untuk anak-anak berlokasi di Kota Semarang; (2) Dokter Pustaka Lampung, merupakan komunitas dan relawan yang membantu pasien anak sehingga terhibur melalui bahan/buku bacaan bergambar, 
mengusir rasa suntuk, dan kebosanan saat menjalani pengobatan; (3) Komunitas Peduli Generasi Dokter Pustaka, merupakan komunitas dan relawan peduli generasi untuk menghibur anak-anak dan para orangtua melalui bahan bacaan dan lagu-lagu ketika sedang di rawat diruang perawatan rumah sakit. Ke tiga layanan Dokter Pustaka di atas merupakan kegiatan suatu komunitas kedokteran yang berusaha memberikan layanan tambahan dalam bidang literasi berbasis buku cetak dan hiburan.

Layanan Dokter Pustaka FKKMK UGM ditujukan untuk pengguna layanan perpustakaan (pemustaka) yang telah selesai menempuh pendidikan formal di FKKMK UGM atau disebut sebagai alumni. Para alumni ini sebagian besar sudah bekerja sebagai dokter, perawat, dan residen di berbagai wilayah di Indonesia. Pemberian layanan ke pemustaka melalui media online, seperti email dan media sosial, yang diberikan secara gratis kepada pemustaka Bagi pustakawan dan perpustakaan FKKMK UGM, layanan Dokter Pustaka menjadi brand dan media layanan referensi online untuk menggerakkan program literasi digital ke pemustaka dan masyarakat. Pustakawan dan perpustakaan harus melakukan branding melalui kinerja pustakawan yang berusaha membangun hubungan baik dengan pemustaka termasuk alumni (Komariah, Rodiah, \& Saepudin, 2016). Untuk mewujudkan brand terbai, Dokter Pustaka melakukan branding yang melekat dan sejalan dengan tingkah laku, etika serta moral pustakawan dan perpustakaan. Kehidupan pribadi pustakawan (Dokter Pustaka) selayaknya menjadi tolak ukur sebuah image yang ingin dibangun (Hariri, 2018).

Pustakawan harus terlibat dalam berbagai program inisiatif literasi kesehatan, baik melalui kegiatan pelatihan, studi penelitian, dan proyek advokasi (Klem et al., 2019). Para alumni telah menjadikan layanan Dokter Pustaka sebagai media alternatif utama dalam pencarian sumbersumber referensi digital dan informasi mutakhir bidang kesehatan. Hal tersebut sangat bermanfaat bagi alumni khususnya mendukung tugas dan pekerjaan alumuni dalam memberikan pelayanan kesehatan di masyarakat, serta pengembangan karir dalam program riset bidang kesehatan di daerah-daerah. Makalah ini membahas tentang pemanfaatan layanan informasi online Dokter Pustaka Perpustakaan FKKMK UGM bagi alumni. Pemanfaatan layanan ini ditinjau dari aspek profil pengguna layanan Dokter Pustaka, pemahaman alumni terhadap literasi kesehatan; dan pemanfaatan layanan Dokter Pustaka Perpustakaan FKKMK UGM.

\section{METODE PENELITIAN}

Kajian ini mendeskripsikan suatu aktivitas layanan informasi online Dokter Pustaka bagi alumni FKKMK UGM. Data yang digunakan bersumber dari studi literatur, diskusi WhatsAppGroup (WAG), dan kuesioner. Melalui WAG, diskusi (tanya-jawab) dapat dilakukan interaktif berdasarkan ruang lingkup pembicaraan yang telah ditetapkan. Komunikasi sesama anggota WAG lebih bersahabat dan menyenangkan (Bouhnik \& Deshen, 2014). Data yang terkumpul dijabarkan secara deskriptif dengan metode kualitatif-kuantitatif. Literatur yang digunakan sebagai kajian adalah artikel jurnal yang relevan dengan pokok bahasan. Diskusi dilakukan secara interaktif antara pustakawan dan alumni di WAG (Gambar 1). Pertanyaan disebarkan secara online melalui platform Google Form (Gambar 2) melalui WAG dan email. 

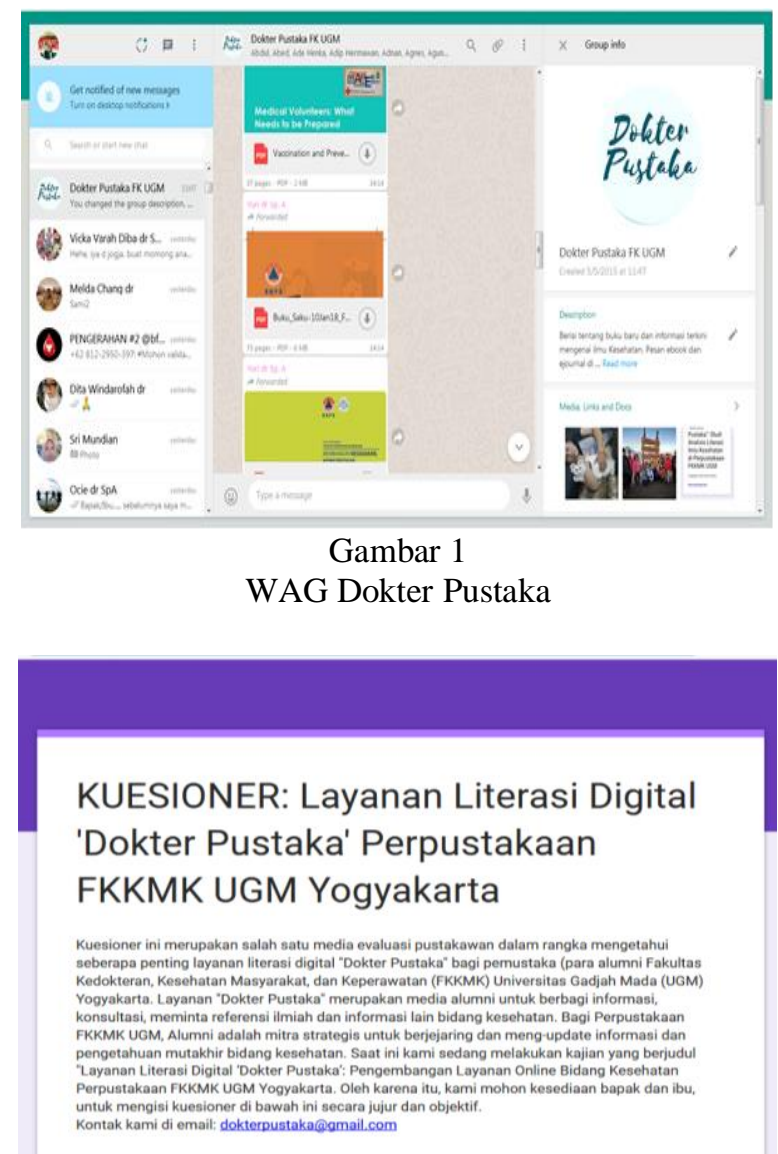

Gambar 2

Form Kuesioner Kajian

Sumber: http://bit.ly/2lEEF3H

Kuesioner ini untuk mengetahui respon atau feedback alumni terhadap masalah pemahaman literasi kesehatan dan kebutuhan informasi mereka setalah memanfaatkan layanan Dokter Pustaka FKKMK UGM. Jumlah responden yang mengisi kuesioner sejumlah 84 orang dari 100 kuesioner yang disebarkan kepada responden. Data yang terkumpul disajikan secara deskriptif pada bagian pembahasan, dan menjadi dasar kesimpulan.

\section{HASIL DAN PEMBAHASAN}

\section{Profil Responden}

Berdasarkan data kuesioner diketahui ada 84 responden yang merespon dan mengisi kuesioner. Data kuesioner terdiri dari profil responden (profesi, instansi, daerah) dan pokok pembahasan, yakni mengenai pemahaman responden (alumni) terhadap literasi kesehatan dan dan kebutuhan informasi responden setelah menggunakan layanan Dokter Pustaka FKKMK UGM. Dari 84 responden diketahui bahwa profesi responden yang mengisi kuesioner sebagian besar adalah dokter spesialis (76 orang), dokter umum (4 orang), residen ( 3 orang), dan perawat (1 orang). Hal Tersebut dapat dilihat pada Gambar 3. 


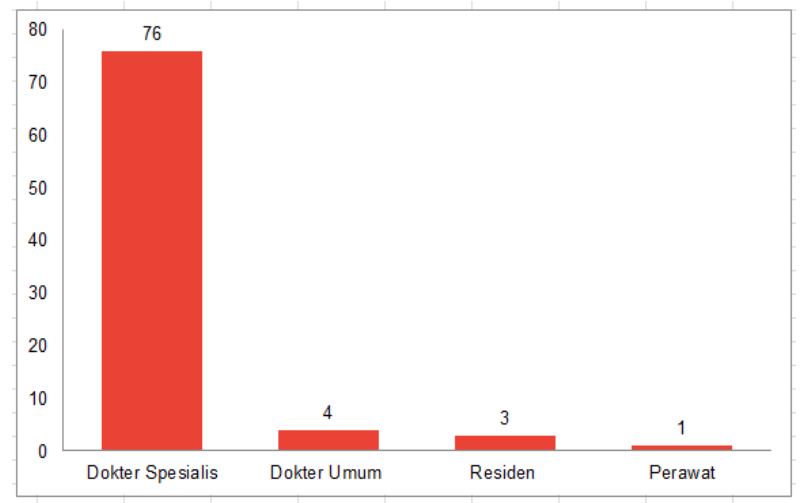

Gambar 3

Profil Responden Berdasarkan Profesi

Dokter Spesialis adalah alumni yang lulus magister kesehatan klinis (S2) dan pendidikan dokter spesialis (double degree). Dokter spesialis merupakan profesi yang paling banyak karena mereka diwajibkan mengisi kuesioner layanan tambahan untuk alumni ketika mengurus bebas pustaka di Perpustakaan FKKMK UGM. Sementara dokter umum, residen, dan perawat tidak diwajibkan (optional) mengisi kuesioner layanan tambahan ketika lulus dari FKKMK UGM. Dokter umum adalah tenaga medis yang memiliki kompetensi dan sertifikasi profesi ilmu kedokteran - mereka merupakan alumni yang lulus S1 dan profesi kedokteran. Residen adalah dokter umum yang melanjukan studi S2 ilmu kesehatan klinis dan program studi dokter spesialis (double degree). Perawat adalah tenaga medis yang berasal dari alumni sarjana ilmu keperawatan dan profesi keperawatan.

Dilihat berdasarkan sebaran instansinya, diketahui ada dua instansi responden yaitu rumah sakit (80 orang) dan universitas (4 orang). Instansi rumah sakit mencakup Rumah Sakit Umum Daerah (RSUD), Rumah Sakit Umum Kota (RSU), Rumah Sakit Umum Pusat (RSUP), Rumah Sakit Ibu dan Anak (RSIA), Rumah Sakit Baptis (RS Baptis), Rumah Sakit Kristen (RS Kristen), Rumah Sakit TNI, dan Rumah Sakit Swasta. Hal Tersebut dapat dilihat pada Gambar 4.

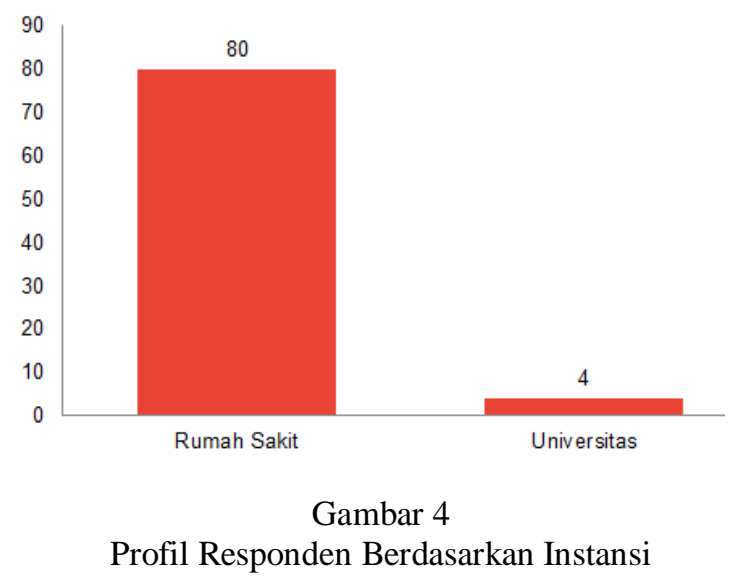

Responden yang bekerja di universitas adalah alumni yang berprofesi sebagai dokter pendidik klinis atau dokdiknis - dokter yang berprofesi sebagai dosen. Mereka bekerja di rumah sakit akademik sebagai klinisi dan praktisi, seperti UGM, Universitas Mataram, dan Universitas Trisakti Jakarta.

Dilihat berdasarkan sebaran wilayah diketahui ada 35 wilayah atau daerah domisili responden. Dari sejumlah 84 responden diketahui bahwa responden yang paling banyak mengisi kuesioner berasal dari kota Yogyakarta, yakni sejumlah 18 orang. Kemudian, diikuti responden yang berdomisili dari Tuban (5 orang); Surakarta, Tangerang, Tegal, dan Temanggung (masingmasing 4 orang), dan sebagainya. Hal tersebut dapat dilihat pada Gambar 5. 


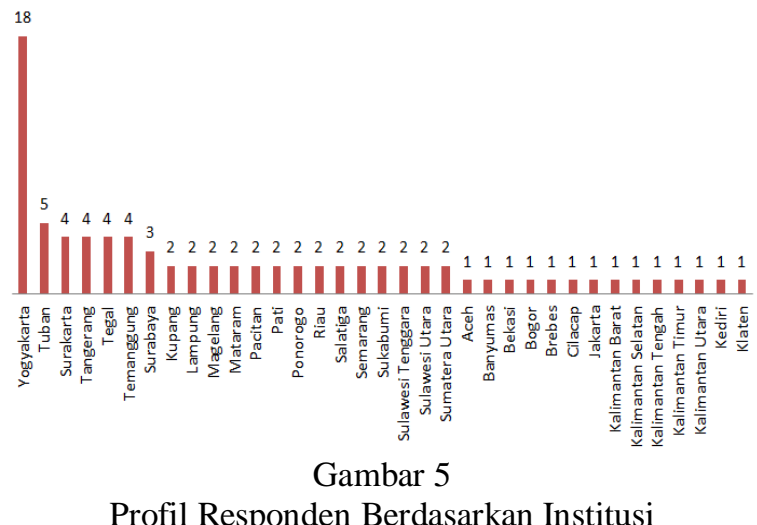

Yogyakarta sebagai tempat domisili responden terbanyak karena mereka setelah lulus dari FKKMK UGM langsung mencari pekerjaan dan menjadi penduduk Yogyakarta yang secara otomatis lebih banyak kontak dan komunikasi dengan pustakawan dan perpustakaan FKKMK UGM.

Ketika para responden menjawab pertanyaan: seberapa penting layanan Dokter Pustaka FKKMK UGM untuk mendukung profesi Anda? Mereka menjawab 'sangat penting' (74 orang) untuk mendukung tugas dan pekerjaan sebagai tenaga medis di daerah (Gambar 6). Kemudian ketika menjawab pertanyaan: apakah Anda puas terhadap layanan Dokter Pustaka? Mereka menjawab 'sangat puas' (65 orang) terhadap layanan Dokter Pustaka di Perpustakaan FKKMK UGM (Gambar 7).

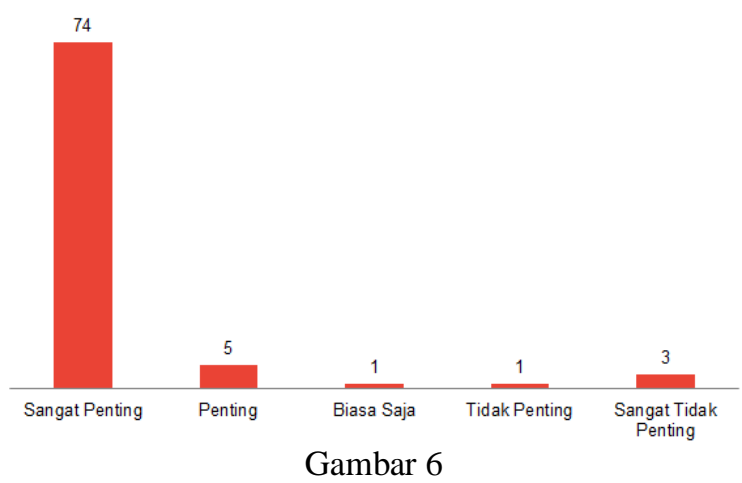

Tanggapan Responden Terhadap Urgensi Layanan Dokter Pustaka

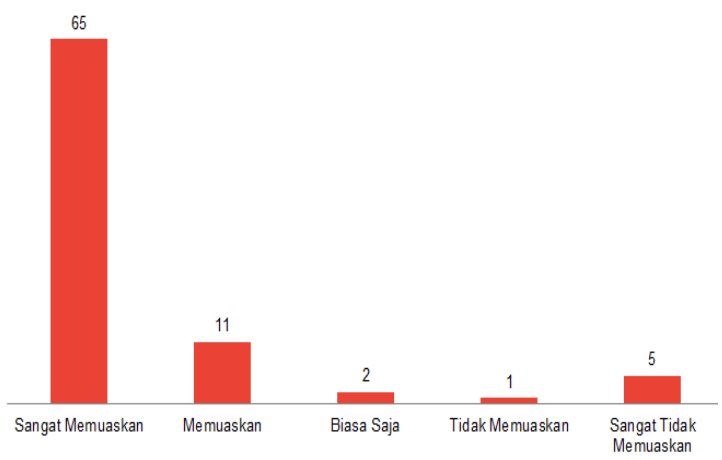

Gambar 7

Tanggapan Responden Terhadap Kepuasan Layanan Dokter Pustaka

Berdasarkan Gambar 6 terlihat ada beberapa responden yang menjawab penting ( 5 orang), sangat tidak penting ( 3 orang), biasa saja bahkan tidak penting (masing-masing 1 orang). Para 
responden yang mengatakan bahwa layanan Dokter Pustaka 'tidak penting' dan 'sangat tidak penting' berpendapat bahwa mereka sudah memiliki akses informasi digital ilmiah ke beberapa database global secara gratis dan open access, seperti Pubmed (https://www.ncbi.nlm.nih.gov/pubmed/), Clinical Key (https://www.clinicalkey.com/\#!/), Cochrane Library (https://www.cochranelibrary.com/), dan sebagainya. Berdasarkan Gambar 7 terlihat juga ada beberapa responden yang menjawab puas (11 orang), sangat tidak memuaskan (5 orang), biasa saja (2 orang), dan tidak puas (1 orang). Para responden yang mengatakan bahwa layanan Dokter Pustaka yang diberikan kepada alumni 'tidak memuaskan' dan 'sangat tidak memuaskan' berpendapat bahwa mereka belum mendapatkan koleksi digital yang dipesan, dan apabila koleksi tersebut itu diperoleh, pemesan harus membelinya dengan harga yang mahal.

\section{Pemahaman terhadap Literasi Bidang Kesehatan}

Literasi kesehatan merupakan salah satu kegiatan literasi informasi sebagaimana yang telah sering didiskusikan dalam dunia kepustakawanan. Literasi informasi sebagai proses untuk memperoleh pengetahuan terhadap perilaku dan keahlian bidang informasi, serta sebagai penentu utama dari cara manusia dalam mengeksploitasi kenyataan, membangun hidup, bekerja, dan berkomunikasi dalam komunitas informasi (Hepworth, 1999; Irawati; 2005; (Sukirno, 2015).

Literasi kesehatan merupakan pemahaman setiap individu dalam hal memperoleh, memproses, dan memahami informasi dan layanan kesehatan dasar yang diperlukan untuk membuat keputusan kesehatan yang tepat (Klem et al., 2019). Pendapat tersebut senada dengan pendapat para responden yang mengatakan bahwa literasi kesehatan merupakan: (1) ilmu yang mempelajari tentang bidang kesehatan, klinis, dan medis, yang menjadi dasar untuk bahan pengambilan keputusan bidang kesehatan berdasarkan prosedur, stnadar pelayan medis, kajian dan Evidance Based Medicine (EBM); (2) layanan perpustakaan online yang menyediakan bahan pustaka dan literatur yang up-todate, cepat, mudah, dan murah dengan konten buku cetak, jurnal, dan informasi lain bidang kesehatan; (3) kompetensi atau kemampuan seorang tenaga kesehatan/medis dalam membaca, memahami, mengolah, memproses informasi dan literatur bidang kesehatan. Kompetensi literasi kesehatan menjadi landasan berpikir tenaga medis (dokter, perawat, dan residen) dalam mengemban tugas dan pekerjannya secara legal dan profesional. Kompetensi ini menjadi landasan kerja tenaga kesehatan /medis secara profesional berdasarkan landasan ilmiah. Kompetensi ini diperoleh melalui suatu proses pembelajaran antara teori, konsep, kajian dan aplikasinya dalam bidang kesehatan.

Kompetensi di atas merupakan implementasi layanan Dokter Pustaka untuk membantu kebutuhan literasi kesehatan para alumni dalam melayani masyarakat. Tayla dalam penelitiannya yang berjudul "Health Literacy in People Living With Mental Illness: A Latent Profile Analysis", mengatakan bahwa kebutuhan untuk meningkatkan literasi kesehatan secara keseluruhan dan mempertimbangkan pendekatan yang dibagi untuk meningkatkan domain literasi kesehatan tertentu (Degan et al., 2019). Konseptualisasi yang lebih baru membedakan antara keterampilan yang dimiliki seseorang untuk mendapatkan informasi kesehatan (literasi kesehatan fungsional), untuk mengekstraksi makna dari informasi yang diperoleh (literasi kesehatan interaktif), dan untuk secara kritis menganalisis informasi dari berbagai sumber untuk tujuan membuat keputusan terkait kesehatan literasi (Klem et al., 2019). Penelitian di atas memiliki kesamaan persepsi dengan kebutuhan alumni FKKMK UGM, yaitu kebutuhan untuk meningkatkan literasi kesehatan dan mempertimbangkan pendekatan ilmiah dalam evidance based medicine. Alumni juga sangat membutuhkan literasi kesehatan, baik fungsional maupun interaktif untuk mendukung kinerja alumni di daerah dengan sumber informasi yang tepat dan akurat. 


\section{Pemanfaatan Layanan 'Dokter Pustaka' bagi Alumni}

Layanan Dokter Pustaka dikelola oleh enam orang yang terdiri dari 1 orang pustakawan dan 5 orang alumni (dokter) FKKMK UGM. Pustakawan bertugas (1) mengelola email, media sosial seperti Facebook (Gambar 8), WAG (Gambar 1), Telegram (Gambar 9 ), dan form layanan online (Gambar 10); (2) membantu mencarikan literatur ilmiah alumni, membagikannya melalui media sosial dalam bentuk link (Gambar 11), dan posting content melalui Instagram (Gambar 12). Sedangkan tugas alumni adalah membagikan informasi mutakhir kegiatan seminar dan konferensi tentang kesehatan, seperti materi lengkap seminar dan prosiding bidang kesehatan, bacaan populer/ berita, dan dokumentasi kerja penunjang pekerjaan bidang kesehatan.

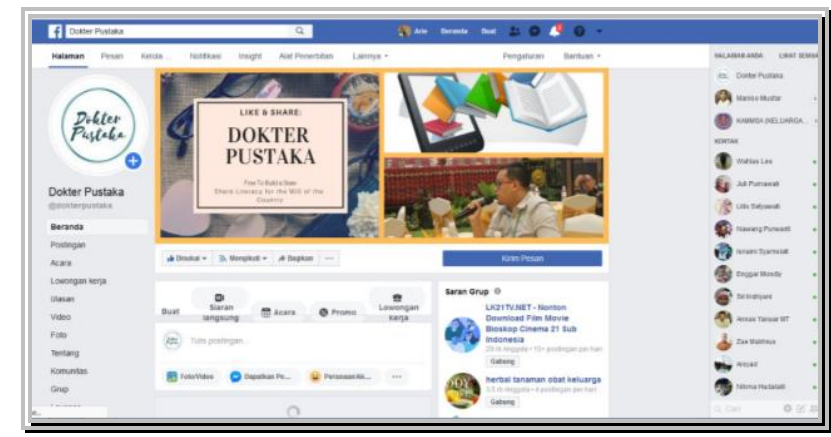

Gambar 8

Facebook Dokter Pustaka

Sumber: https://www.facebook.com/dokterpustaka/

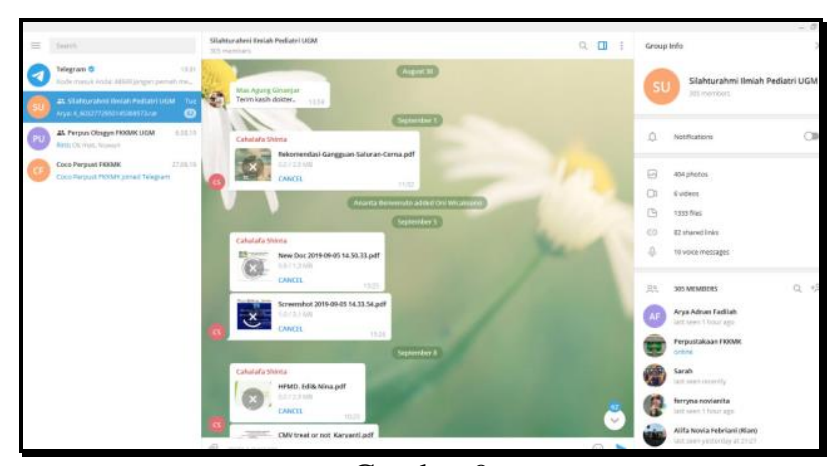

Gambar 9

Layanan Daring Telegram

Formulir Pemesanan Referensi Online 'Dokter Pustaka' UGM

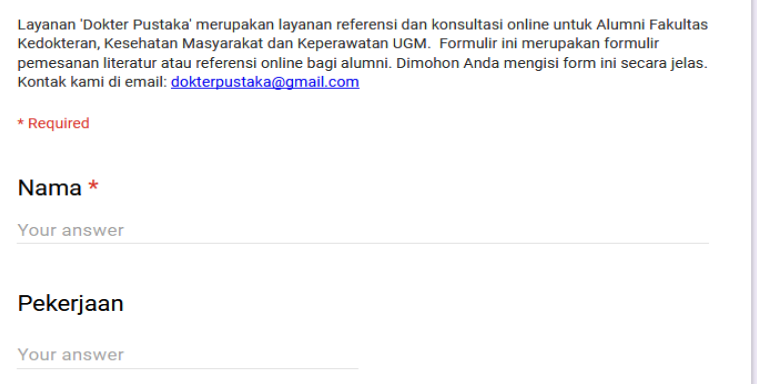

Gambar 10

Form Layanan Online Dokter Pustaka

Sumber: http://bit.ly/21JudIn 


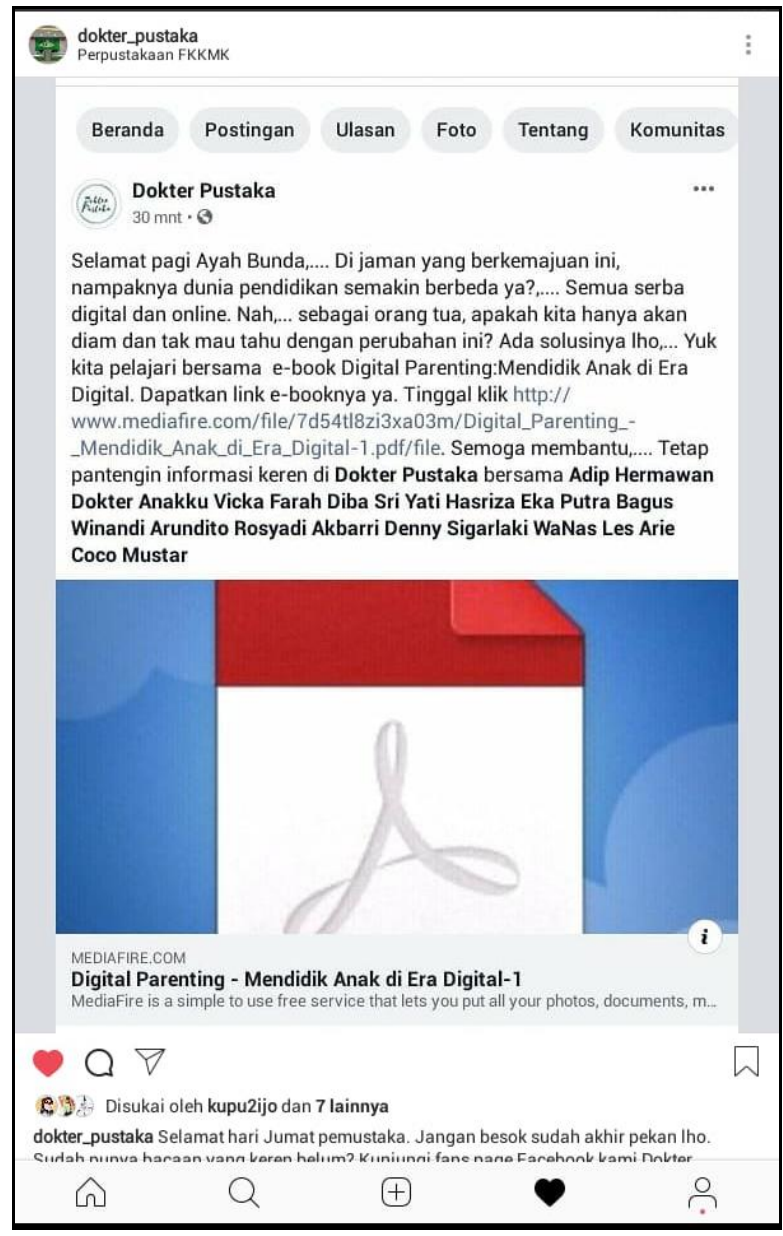

Gambar 11

Berbagi File Koleksi melalui link Mediafire di Facebook Dokter Pustaka

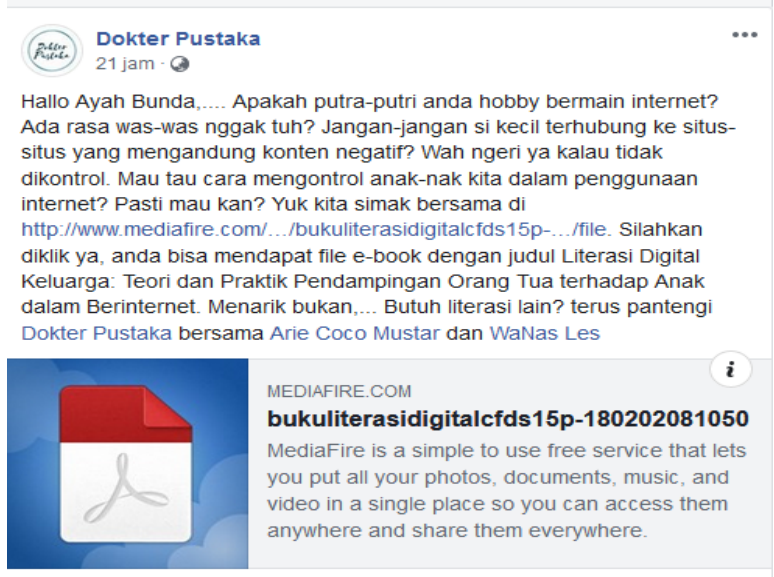

\section{Gambar 12}

Posting content layanan Dokter Pustaka melalui Instagram

Alumni dapat memanfaatkan layanan Dokter Pustaka selama 24 jam, dan jika membutuhkan bantuan penelusuran informasi lebih lanjut dipersilakan menghubungi WA group, mengisi formulir pemesanan atau mengirim email ke petugas di dokterpustaka@gmail.com. Ada beberapa alasan Perpustakaan FKKMK UGM menyediakan layanan informasi online Dokter Pustaka, antara lain: 1). Alumni merupakan bagian dari pelanggan eksternal yang harus tetap dilayani oleh pustakawan dan perpustakaan meskipun sudah tidak melakukan pembelajaran di FKKMK UGM. Alumni selalu meng-update informasi dan pengetahuannya melalui bahan bacaan atau literatur (ilmiah dan populer) untuk menunjang pekerjaan dan tindak lanjut pendidikan 
mereka. 2). Adanya keterbatasan anggaran untuk pembelian buku bidang kesehatan, akses informasi dan literatur ilmiah bidang kesehatan khusus bagi alumni yang tinggal di daerah terpencil atau daerah terluar di wilayah Indonesia. Alumni berharap melalui layanan Dokter Pustaka, mereka memperoleh akses e-rosources yang dilanggan oleh UGM, seperti clinical key, clinical up to date, medline with full text, cochrane library, dsb. Setelah memperoleh informasi dan literatur yang diharapkan, mereka dapat mengimplementasikannya sesuai dengan prosedur layanan kesehatan, standar pelayan medis dan Evidance Based Medicine (EBM)

Responden yang melakukan diskusi di WAG Dokter Pustaka mengatakan bahwa layanan ini dapat digunakan sebagai media pembelajaran online atau e-learning yang efektif dan interaktif antara pustakawan dan alumni FKKMK UGM. E-learning di perpustakaan menjadi media antara mahasiswa maupun dosen untuk dapat memanfaatkan koleksi perpustakaan, walaupun tanpa berkunjung ke perpustakaan. Pengguna dapat memanfaatkan layanan e-learning di perpustakaan untuk konsultasi secara pribadi (Wulandari \& Nugroho, 2017). Para alumni dapat memanfaatkan ribuan judul koleksi digital secara fulltext dan gratis, yang terdiri dari e-book, e-journal, dan $e$ proceeding. Terkait ketersediaan e-resources tersebut, para responden berharap agar pustakawan di Perpustakaan FKKMK UGM dapat membantu pencarian literatur ilmiah bidang kesehatan sesuai kebutuhan, baik dalam bentuk digital maupun tercetak (printed). Adapun topik literatur yang disediakan mencakup: (1) pediatric (ilmu kesehatan anak, seperti neuropediatric, gastroenterology-hepatology, hemato-onkology, tumbuh kembang anak dan remaja, infeksi, nefrology, cardiology, perinatology, respirology, kegawatdaruratan, gizi dan metabolik); (2) obsgin (ilmu penyakit kandungan); (3) surgery (ilmu bedah); dan emergency (ilmu kedaruratan seperti kecelakaan dan penyakit lanjutan yang sudah tidak tertangani di bangsal perawatan). Selain itu, para alumni juga dapat berkonsultasi dengan pustakawan tentang perihal penulisan dan penyusunan karya tulis ilmiah, untuk jurnal dan prosiding. Materi konsultasi yang diberikan pustakawan berupa modul pemanfaatan aplikasi reference manager (Mendeley) untuk penulisan kutipan dan daftar pustaka, serta pemanfaatan e-resources ilmiah universitas untuk bahan referensi penulisan ilmiah (UGM, 2019). Jika di database e-resources universitas dan global tidak tersedia, pustakawan membantu mencarikan bekerja sama dengan sejawat pustakawan melaui group pustakawan dan atau membelikan koleksi cetak (biayanya dibebankan kepada pemesan), dan koleksi yang dipesan akan dikirim sesuai alamat pemesan.

\section{SIMPULAN}

Layanan informasi online Dokter Pustaka memberikan kemudahan akses informasi bagi para Alumni FKKMK UGM. Alumni dapat memanfaatkan layanan ini untuk kepentingan pencarian koleksi/literatur ilmiah dan meng-update informasi mutakhir bidang kesehatan. Referensi yang diperoleh alumni melalui layanan informasi online Dokter Pustaka sangat mendukung pelaksanaan tugas dan pekerjaan mereka di daerah. Berdasarkan pembahasan di atas dapat disimpulkan bahwa: (1) sebagian besar responden yang berprofesi sebagai dokter spesialis (75 orang) berpendapat bahwa layanan informasi online Dokter Pustaka sangat penting dan mereka mendapatkan kepuasan dalam memanfaatkan layanan tersebut; (2) pemahaman alumni terhadap literasi kesehatan sudah baik, terlihat pada argumen mereka yang mengatakan bahwa literasi kesehatan adalah ilmu tentang kesehatan, klinis, dan medis yang dapat meningkatkan kompetensi untuk mendukung tugas dan pekerjaan mereka sebagai tenaga medis di daerah; dan (3) kebutuhan informasi responden melalui layanan dari Dokter Pustaka FKKMK UGM beragam, baik berupa literatur ilmiah (seperti buku tercetak, e-book, e-journal, dan e-proceeding) maupun informasi mutakhir bidang kesehatan. 


\section{DAFTAR PUSTAKA}

Bouhnik, D., \& Deshen, M. (2014). WhatsApp Goes to School: Mobile Instant Messaging Between Teachers and Students. Journal of Information Technology Education: Research, 13, 217-231.

Clotfelter, C. T. (2003). Alumni Giving to Elite Private Colleges and Universities. Economics of Education Review, 22(2), 109-120. doi:10.1016/s0272-7757(02)00028-6

Degan, T. J., Kelly, P. J., Robinson, L. D., Deane, F. P., Wolstencroft, K., Turut, S., \& Meldrum, R. (2019). Health Literacy in People Living With Mental Illness: A latent profile analysis. Psychiatry Research, 280(July), 112499. https://doi.org/10.1016/j.psychres.2019.112499.

Dewi, N. \& Prihartanti, N. (2014). Metode Biblioterapi dan Diskusi Dilema Moral untuk Pengembangan Karakter Tanggungjawab. Jurnal Psikologi, Volume 41, No.1, Juni: 47 59.

Dunn, P., \& Hazzard, E. (2019). Technology Approaches to Digital Health Literacy. International Journal of Cardiology, 293, 294-296. https://doi.org/10.1016/j.ijcard.2019.06.039

Hariri, A. (2018). Strategi Personal Branding Pustakawan di Perpustakaan Universitas Muhammadiyah Purwokerto. In Proceedings Disruptive Technology: Opportunities and Challenges for Libraries and Librarians (pp. 175-185).

Kim, S., Lee, J. G., \& Yi, M. Y. (2017). Developing Information Quality Assessment Framework of Presentation Slides. Journal of Information Science, 43(6), 742-768. https://doi.org/10.1177/0165551516661917

Klem, M. L., Saleh, A. A., Devine, P. J., Gutzman, K. E., Knehans, A. C., Mills, T. N., ... Vardell, E. (2019). Librarians and Health Literacy: A Scoping Review. Library and Information Science Research, 41(2), 102-108. https://doi.org/10.1016/j.lisr.2019.04.005

Komariah, N., Rodiah, S., \& Saepudin, E. (2016). Emotional Branding sebagai Upaya Pengembangan Kualitas Layanan Perpustakaan untuk Meningkatkan Penggunaan Perpustakaan. Record and Library Journal, 2(02), 188-197. https://doi.org/10.20473/rlj.v2i2.3070

Maulana, M. (2015). Definisi, Manfaat dan Elemen Penting Literasi Digital. Seorang Pustakawan Blogger, 1-12. Retrieved from https://www.muradmaulana.com/2015/12/definisi-manfaat-dan-elemen-penting-literasidigital.html

Nashihuddin, W., \& Tupan. (2013). Pemanfaatan Layanan Online: Studi Kasus Pada Jasa Meja Informasi dan Penelusuran Informasi PDII-LIPI Tahun 2008-2012, Visi Pustaka, Vol. 15, No. 1, April.

Saepudin, E. (2013). Literasi Informasi Kesehatan Lingkungan Pada Masyarakat Pedesaan: Studi Deskriptif Di Desa Nagrog Kecamatan Cicalengka. Jurnal Kajian Informasi Dan Perpustakaan, 1(1), 81. https://doi.org/10.24198/jkip.v1i1.9614

Sukirno. (2015). Membangun Literasi Informasi Perpustakaan melalui Pendidikan Pemakai - 
Kompasiana.com. $\quad$ Retrieved September $\quad 9, \quad 2019$, from https://www.kompasiana.com/pustakawan/5512daf08133113644bc601b/membangunliterasi-informasi-perpustakaan-melalui-pendidikan-pemakai.

UGM. (2019.). E-resources, Database, Jurnal, dan Buku Elektronik Online - Perpustakaan. Retrieved September 9, 2019, from http://lib.ugm.ac.id/ind/?page_id=194

Wahyuningsih, T. (2019). Faktor-Faktor Yang Mempengaruhi Literasi Kesehatan Masyarakat Di Puskesmas, 02(01), 26-31.

Wulandari, NER. \& Nugroho, E. (2017). E-Learning: Implikasinya Terhadap Pelayanan Perpustakaan Perguruan Tinggi dan Peran Pustakawan. Berkala Ilmu Perpustakaan dan Informasi, Vol. 13 No. 1, Juni, 87-96. DOI: http://10.22146/bip.26199 